\title{
IMPLEMENTASI MODEL PEMBELAJARAN KOOPERATIF TEKNIK TEAM ACCELERATED INSTRUCTION (TAI) UNTUK MENINGKATKAN MOTIVASI BELAJAR AKUNTANSI SISWA KELAS XI IPS 2 SMA NEGERI 1 BANGUNTAPAN TAHUN AJARAN 2012/2013
}

\section{Oleh : Ardy Pratama Putra W}

Prodi Pendidikan Akuntansi Universitas Negeri Yogyakarta Ardy.pratama.pw@gmail.com

Isroah

Staf Pengajar Jurusan P. Akuntansi Universitas Negeri Yogyakarta

\begin{abstract}
Abstrak
Penelitian ini bertujuan untuk meningkatkan Motivasi Belajar Akuntansi Kelas XI IPS 2 SMA N 1 Banguntapan Tahun Ajaran 2012/2013 dengan Implementasi Model Pembelajaran Kooperatif Teknik Team Accelerated Instruction (TAI). Penelitian ini merupakan penelitian tindakan kelas (PTK) dengan subjek penelitian siswa kelas XI IPS 2 SMA N 1 Banguntapan Tahun Ajaran 2012/2013yang berjumlah 24 siswa. Penelitian ini dilaksanakan dalam bentuk kolaboratif dan partisipatif yang dilaksanakan dalam dua siklus. Pengumpulan data penelitian ini dilakukan dengan observasi dan angket. Analisis data yang dilakukan adalah analisis data deskriptif kuantitatif dengan persentase yang dilakukan dengan menghitung skor Motivasi Belajar Akuntansi, menyajikan data dan penarikan kesimpulan. Berdasarkan hasil penelitian disimpulkan bahwa Implementasi Model Pembelajaran Kooperatif Teknik Team Accelerated Instruction (TAI)dapat meningkatkan Motivasi Belajar Akuntansi siswa kelas XI IPS 2 SMA Negeri 1 Banguntapan tahun ajaran 2012/2013 yang dibuktikan dengan adanya peningkatan persentase skor Motivasi Belajar Akuntansi dari sebelum Implementasi Teknik Team Accelerated Instruction (TAI) sebesar $63,15 \%$ meningkat sebesar $16,41 \%$ menjadi $79,56 \%$ di siklus 1 . Selanjutnya dari siklus 1 ke siklus 2 juga diperoleh skor sebesar $84,90 \%$ atau terjadi peningkatan sebesar 5,34\%. Selain itu berdasarkan angket yang didistribusikan kepada siswa dapat disimpulkan pula bahwa terjadi peningkatan skor Motivasi Belajar Akuntansi siswa dari skor siklus 1 sebesar 77,60\% meningkat sebesar 4,29\%, sehingga diperoleh skor siklus 2 sebesar $81,89 \%$.
\end{abstract}

Kata Kunci: Pembelajaran kooperatif, TAI, Motivasi Belajar Akuntansi.

\section{Abstract}

This research is aims to Improve Accounting Learning Motivation through Implementation Cooperative Learning Team Accelerated Instruction (TAI) Model class XI Social 2 SMA N 1 Banguntapan academic year 2012/2013. This research is Classroom Action Research which subject is students from class XI Social 2 SMA N 1 Banguntapan academic year 2012/2013 who have 24 students. This study was conductedin a collaborative and participatory conducted in two cycles. Research data collection was conducted by observation and questionnaires. Data 
analysis is descriptive quantitative data analysisis done by calculating the percentage ofscores Motivation Accounting, presenting data and drawing conclusions. Based on the result of the research concluded that Implementation Cooperative Learning Team Accelerated Instruction (TAI) Model can improve Accounting Learning Motivation student class XI Social 2 SMA N 1 Banguntapan academic year 2012/2013 evidenced by theincrease inthe percentage ofscores Motivation Accounting from before Implementation Cooperative Team Accelerated Instruction (TAI) Model amounted to63.15\% increased by $16.41 \%$ to $79.56 \%$ incycle 1.Furthermore, fromcycle 1tocycle 2alsoobtaineda score of $84.90 \%$ oran increase of $5.34 \%$. Also based ona questionnairedistributed tostudents canbe concluded also that an increase in the scores of students' motivation to learn Accounting Cycle 1 score amounted to $77.60 \%$ increased by $4.29 \%$, so the obtained score of cycle 2 amounted to $81.89 \%$.

Keywords: cooperative learning, TAI, Accounting Learning Motivation.

\section{A. PENDAhuluan}

Pendidikan adalah usaha sadar dan terencana untuk mewujudkan suasana belajar dan proses pembelajaran agar peserta didik secara aktif mengembangkan potensi dirinya untuk memiliki kekuatan spiritual keagamaan, pengendalian diri, kepribadian, kecerdasan, akhlak mulia, serta keterampilan yang diperlukan dirinya dan masyarakat, bangsa dan negara.

Pendidikan dikatakan berhasil jika tercapai peningkatan kualitas pendidikan.Peningkatan kualitas pendidikan dapat dilihat dari meningkatnya hasil belajar siswa.Hasil belajar siswa dapat meningkat apabila siswa dapat berhasil dalam belajar.Usaha dan keberhasilan belajar dipengaruhi oleh banyak faktor. Faktor-faktor yang mempengaruhi usaha dan keberhasilan belajar dapat bersumber pada diri siswa atau lingkungan siswa. Faktor yang ada pada diri individu menyangkut a) aspek jasmaniah yang dapat dibedakan menjadi dua macam yaitu keadaan jasmani pada umumnya dan fungsi alat-alat tubuh serta fungsi panca indera; b) aspek psikis, yang meliputi kondisi kesehatan psikis, kemampuan-kemampuan intelektual, sosial, psikomotor, kondisi afektif dari individu. Kondisi afektif berupa motivasi untuk belajar.Belajar perlu didukung oleh motivasi yang kuat dan konstan. Motivasi yang lemah dan tidak konstan akan menyebabkan kurangnya usaha belajar, yang pada akhirnya akan berpengaruh terhadap hasil belajar.

Peningkatankualitas pendidikan dapat dilihat dari meningkatnya hasil belajar atau prestasi belajar yang diperoleh siswa.Salah satu hal yang dapat meningkatkan hasil atau prestasi belajar tersebut adalah dengan meningkatkan motivasi belajar.Motivasi merupakan daya penggerak bagi seseorang untuk menjadi aktif.Seseorang menjadi aktif pada saat-saat tertentu, terutama bila kebutuhan dirasakan atau mendesak. Dampak motivasi dalam proses pembelajaran yang ada di kelas dapat berupa serangkaian usaha untuk menyediakan kondisi-kondisi tertentu, sehingga siswa mau dan bertindak untuk melakukan sesuatu guna mencapai tujuan pembelajaran. 
Model pembelajaran kooperatif merupakan model pembelajaran yang memungkinkan siswa belajar secara aktif dan partisipatif. Model pembelajaran ini memaksimalkan kegiatan belajar dengan cara mengelompokkan siswa dalam kelompok-kelompok kecil dan saling belajar bersama. Berbagai macam teknik dalam pembelajaran kooperatif diantaranya yaitu teknik Team Accelerated Instruction (TAI).Teknik ini mengkombinasikan keunggulan pembelajaran kooperatif dan pembelajaran individual.Tipe ini dirancang untuk mengatasi kesulitan belajar siswa secara individual.Oleh karena itu kegiatan pembelajarannya lebih banyak digunakan untuk pemecahan masalah, ciri khas pada tipe TAI ini adalah setiap siswa secara individual belajar materi pembelajaran yang sudah dipersiapkan oleh guru.Hasil belajar individual dibawa ke kelompok-kelompok untuk didiskusikan dan saling dibahas oleh anggota kelompok, dan semua anggota kelompok bertanggung jawab atas keseluruhan jawaban sebagai tanggung jawab bersama.

Pembelajaran yang dilakukan di kelas akan berlangsung secara efektif jika guru dapat memilih metode yang sesuai dengan keadaan yang ada dalam kelas tersebut. Setiap guru akan menggunakan metode yang berbeda-beda satu sama lain. Pembelajaran yang dilakukan dengan melibatkan aktivitas siswa akan lebih diminati oleh siswa daripada pembelajaran yang menjadikan siswa pasif. Pembelajaran konvensional yang ada saat ini merupakan pembelajaran yang menuntut keaktifan guru dalam menyampaikan pembelajaran dan menjadikan siswa pasif.Hal tersebut membuat siswa cenderung pasif dan tidak terlalu berminat terhadap pembelajaran.

Tingginya intensitas penggunaan metode ceramah yang dilakukan oleh guru menjadikan siswa tidak melakukan banyak aktivitas, sehingga guru mengalami kesulitan dalam membangkitkan motivasi siswa terhadap mata pelajaran yang diajarkan, terutama untuk mata pelajaran yang didalamnya memerlukan banyak proses menghitung, contohnya seperti pada mata pelajaran Akuntansi. Rendahnya motivasi terhadap pembelajaran akan mengakibatkan siswa tidak dapat memahami materi pelajaran dengan baik. Hal ini juga akan berpengaruh terhadap prestasi belajar siswa.

Pembelajaran yang dapat meningkatkan motivasi siswa selama proses pembelajaran adalah metode yang menggunakan pendekatan pembelajaran aktif, diantaranya adalah Metode Pembelajaran Kooperatif. Metode Pembelajaran Kooperatif tidak hanya membelajarkan kecakapan akademik saja, namun juga keterampilan sosial. Penggunaan berbagai teknik dalam metode pembelajaran kooperatif, diantaranya Teknik Pembelajaran Team Accelerated Instruction (TAI), dapat menjadikan siswa memusatkan perhatian kepada pembelajaran, sehingga siswa akan semakin termotivasi dan pemahaman siswa terhadap materi pembelajaran dapat ditingkatkan, sekaligus juga membelajarkan keterampilan sosial. Hal tersebut tampak dari adanya kerja sama antar siswa dalam Teknik Pembelajaran Team Accelerated Instruction (TAI) sebagai upaya untuk memahami konsep dalam materi pelajaran. Kerja sama tersebut akan melatih keterampilan siswa dalam hal bersosialisasi dengan teman sebaya dan juga akan berpengaruh terhadap meningkatnya prestasi belajar siswa. 
Berdasarkan pengamatan yang dilakukan terhadap proses pembelajaran kelas XI IPS 2 SMA Negeri 1 Banguntapan, guru mata pelajaran akuntansi menjelaskan materi masih terpaku pada penggunakan metode ceramah dan latihan sehingga menyebabkan siswa cenderung pasif dan kurang bersemangat dalam mengukiti pembelajaran. Hal tersebut ditunjukkan dengan adanya 34\% siswa suka menunda mengerjakan tugas yang diberikan oleh guru, hanya terdapat $11 \%$ siswa yang bertanya saat guru memberikan kesempatan untuk bertanya, dan hampir 50\% siswa tidak segera masuk kelas saat bel tanda masuk dibunyikan, siswa lebih suka duduk-duduk diluar kelas sambil menunggu guru datang dari pada mempersiapkan pelajaran. Pada saat proses pembelajaran ditemukan beberapa siswa tidur saat guru menerangkan materi. Dari beberapa temuan di atas maka dapat dikatakan motivasi belajar siswa masih rendah.Berdasarkan hasil wawancara dengan guru mata pelajaran akuntansi, saat ini guru masih senang menggunakan metode ceramah dan latihan karena dianggap paling sesuai dengan struktur pembelajaran akuntansi dan mudah dalam persiapannya. Selain itu, faktor kesibukan menjadikan alasan guru untuk menerapkan metode pembelajaran lain.

Berdasarkan permasalahan yang ditemukan tersebut, maka perlu diadakan suatu pemecahan masalah guna memperbaiki proses pembelajaran yang berlangsung di kelas XI IPS 2 SMA Negeri 1 Banguntapan. Solusi pembelajaran yang diharapkan mampu memberikan dorongan atau motivasi belajar siswa. Pembelajaran yang dapat memotivasi siswa selama proses pembelajaran adalah metode pembelajaran kooperatif. Pembelajaran kooperatif saat ini menjadi perhatian dan dianjurkan untuk digunakan.Wina Sanjaya (2011: 243) berpendapat bahwa pembelajaran kooperatif dapat digunakan manakala guru menghendaki meningkatkan motivasi siswa dan menambah tingkat partisipasi mereka.Metode Pembelajaran Kooperatif tidak hanya membelajarkan kecakapan akademik saja, namun juga keterampilan sosial melalui kegiatan pembelajaran di kelas yang dilaksanakan secara berkelompok.Pembelajaran kooperatif memberikan kesempatan kepada siswa untuk bekerja antar siswa yang mempunyai kemampuan heterogen.Sistem pembelajaran gotong royong atau pembelajaran kooperatif memberikan kesempatan kepada anak didik untuk bekerja sesama siswa dalam tugas-tugas terstruktur, sehingga dengan sistem ini siswa lebih berperan aktif dalam pembelajaran sedangkan guru sebagai fasilitator.

Salah satu tipe metode pembelajaran kooperatif yaitu Team Accelerated Instruction (TAI) metode pembelajaran ini dikembangkan oleh Slavin.Tipe ini mengkombinasikan keunggulan pembelajaran kooperatif dan pembelajaran individual.Tipe ini dirancang untuk mengatasi kesulitan belajar siswa secara individual.Oleh karena itu kegiatan pembelajarannya lebih banyak digunakan untuk pemecahan masalah, ciri khas pada tipe TAI ini adalah setiap siswa secara individual belajar materi yang sudah disiapkan oleh guru.Hasil belajar individual dibawa ke kelompok-kelompok untuk didiskusikan dan saling dibahas oleh anggota kelompok, dan semua anggota kelompok bertanggung jawab atas keseluruhan jawaban sebagai tanggung jawab bersama.Sehingga memotivasi siswa untuk mendapatkan hasil yang baik demi kelompoknya. 
Sesuai dengan analisis situasi yang telah disebutkan, peneliti bermaksud melakukan penelitian dengan judul "Implementasi Model Pembelajaran Kooperatif Teknik TeamAccelerated Instruction (TAI) untuk Meningkatkan Motivasi Belajar Akuntansi Siswa Kelas XI IPS 2 SMA Negeri 1 Banguntapan Tahun Ajaran 2012/2013".

Menurut Sardiman A.M. (2011: 73) kata "motif" diartikan sebagai daya upaya yang mendorong seseorang untuk melakukan sesuatu. Motivasi diartikan daya penggerak yang telah menjadi aktif. Sedangkan menurut McDonald dalam Oemar Hamalik (2009: 173) motivasi adalah suatu perubahan energi didalam pribadi seseorang yang ditandai dengan timbulnya afektif dan reaksi untuk mencapai tujuan. Menurut Mustaqim (2008: 34) belajar adalah perubahan tingkah laku yang relatif tetap yang terjadi karena latihan dan pengalaman. Sedangkan menurut Gagne (1984) dalam Ratna Wilis (2011: 2) belajar didefinisikan sebagai suatu proses dimana suatu organisasi berubah perilakunya sebagai akibat pengalaman. Pengertian Akuntansi dikemukakan oleh Al Haryono Yusuf (2001: 4-5) adalah suatu disiplin ilmu yang menyediakan informasi yang diperlukan untuk melaksanakan kegiatan secara efisien dan mengevaluasi kegiatan-kegiatan suatu organisasi. Definisi Akuntansi dari sudut proses kegiatan adalah proses pencatatan, penggolongan, peringkasan, pelaporan, dan penganalisaan data keuangan suatu organisasi.

Pengertian motivasi belajar dikemukakan Hamzah B. Uno (2008: 23) bahwa: Motivasi belajar merupakan dorongan internal dan eksternal pada siswa-siswa yang sedang belajar untuk mengadakan perubahan tingkah laku, pada umumnya dengan beberapa indikator/unsur yang mendukung. Disamping itu menurut pendapat Sardiman A.M. (2011: 75) yaitu: Motivasi belajar dikatakan sebagai keseluruhan daya penggerak di dalam diri siswa yang menimbulkan kegiatan belajar, yang menjamin kelangsungan dari kegiatan belajar dan yang memberikan arah pada kegiatan belajar, sehingga tujuan yang dikehendaki oleh subyek belajar itu dapat tercapai. Berdasarkan uraian tersebut, dapat disimpulkan bahwa motivasi belajar akuntansi adalah dorongan atau daya penggerak psikis baik di dalam diri siswa (internal) maupun dari luar (eksternal) untuk melakukan kegiatan pengidentifikasian, pengesahan, pengukuran, pangakuan, pengklasifikasian, penggabungan, peringkasan, dan penyajian data keuangan dasar dari kejadiankejadian atau transaksi-transaksi dalam perusahaan untuk menghasilkan informasi akuntansi yang dapat disajikan dalam bentuk laporan keuangan.

Slavin(2008: 195-200)berpendapat bahwa pembelajaran kooperatif tipe TAI merupakan salah satu tipe yang mengkombinasikan keunggulan pembelajaran kooperatif dan pembelajaran individual. Tipe ini dirancang untuk mengatasi kesulitan belajar siswa secara individual. Oleh karena itu kegiatan pembelajarannya lebih banyak digunakan untuk pemecahan masalah, ciri khas pada tipe TAI ini adalah setiap siswa secara individual belajar materi yang sudah disiapkan oleh guru. Hasil belajar individual dibawa ke kelompok-kelompok untuk didiskusikan dan saling dibahas oleh anggota kelompok, dan semua anggota kelompok bertanggung jawab atas keseluruhan jawaban sebagai tanggung jawab bersama. 


\section{B. METODE PENELITIAN}

\section{Tempat dan Waktu Penelitian}

Penelitian ini dilaksanakan di kelas XI IPS 2 SMA Negeri 1 Banguntapan yang beralamat di Ngentak, Baturetno, Banguntapan, Bantul, Yogyakarta.Penelitian yang dilakukan meliputi tahap persiapan, pelaksanaan, hingga pelaporan, yang dilakukan pada tanggal 24 April 10 Mei 2013.

\section{Desain Penelitian}

Penelitian ini merupakan Penelitian Tindakan Kelas (PTK) yang dalam bahasa Inggris adalah Classroom Action Research (CAR). Penelitian tindakan kelas merupakan suatu pencermatan terhadap kegiatan belajar berupa sebuah tindakan, yang sengaja dimunculkan dan terjadi dalam sebuah kelas secara bersama (Suharsimi Arikunto, 2009: 3).

\section{Subjek dan Objek Penelitian}

Subjek dalam penelitian ini adalah siswa kelas XI IPS 2 SMA Negeri 1 Banguntapanyang berjumlah 24 siswa. Sedangkan yang menjadi objek penelitian adalah Motivasi Belajar Akuntansi siswa kelas XI IPS 2 SMA Negeri 1 Banguntapan.

\section{Teknik Pengumpulan Data}

a. Pedoman Observasi

Observasi yang dilakukan membutuhkan pedoman tertulis yang memuat indikator-indikator yang akan diamati. Berdasarkan indikatorindikator yang telah ditetapkan. Untuk mendapatkan data yang diinginkan, peneliti membatasi penyusunan Pedoman Observasi hanya terkait dengan Motivasi Belajar Akuntansi siswa yang dapat diamati pada saat pembelajaran Akuntansi berlangsung.

b. Angket

Angket atau kuesioner adalah sejumlah pertanyaan tertulis yang digunakan untuk memperoleh informasi dari responden dalam arti laporan tentang pribadinya atau hal-hal yang ia ketahui (Suharsimi, 2010:194). Angket digunakan untuk mengukur Motivasi Belajar Akuntansi siswa kelas XI IPS 2SMA Negeri 1 Banguntapan setelah penerapan Model Pembelajaran Kooperatif Teknik Team Accelerated Instruction (TAI).

c. Dokumentasi

Dalam penelitian ini, dokumen yang digunakan adalah catatan lapangan, lembar observasi, dan daftar nilai tes siswa.

\section{Instrumen Penelitian}

a. Lembar Observasi

Kisi-kisi Instrumen Motivasi Belajar Akuntansi meliputi: tekun menghadapi tugas, ulet menghadapi kesulitan, memiliki minat terhadap pelajaran, lebih senang bekerja mandiri, cepat bosan pada tugas-tugas rutin, dapat mempertahankan pendapatnya, tidak mudah melepaskan hal yang diyakini dan senang mencari dan memecahkan masalah soal-soal. 


\section{b. Angket}

Dalam menyusun angket telah ditetapkan kisi-kisi yang akan dijadikan dasar dalam menyusun penyataan dalam angket yang meliputi: tekun menghadapi tugas, ulet menghadapi kesulitan, memiliki minat dan perhatian terhadap pelajaran, rasa senang dan puas dalam mengerjakan tugas yang diberikan, adanya hasrat dan keinginan untuk berhasil, adanya kegiatan yang menarik dalam belajar.

c. Catatan Lapangan

Catatan lapangan merupakan catatan yang berfungsi untuk mencatat segala bentuk aktivitas yang dilakukan siswa di dalam kelas selama proses pembelajaran yang dilakukan dengan Model Pembelajaran Kooperatif Team Accelerated Instruction (TAI).

\section{Teknik Analisis Data}

Penelitian ini menggunakan analisis data deskriptif kuantitatif dengan persentase.Untuk menganalisis data tersebut, dilakukan langkahlangkah sebagai berikut:

1. Menghitung Skor Motivasi Belajar Akuntansi

a. Menentukan kriteria pemberian skor terhadap masing-masing aspek pada setiap indikatorMotivasi Belajar Akuntansi yang diamati.

b. Menjumlahkan skor untuk masing-masing aspek pada setiap indikator Motivasi Belajar Akuntansi yang diamati.

c. Menghitung skor motivasi belajar terhadap masing-masing aspek pada setiap indikatorMotivasi Belajar Akuntansi yang diamati dengan rumus:

$\%=$\begin{tabular}{ll|}
\hline Skor hasil Motivasi Belajar Akuntansi Siswa & \\
Skor Maksimum & X 100\% \\
\hline
\end{tabular}

(Sugiyono, 2009: 144)

2. Menyajikan Data

Penyajian data adalah penampilan data secara lebih sederhana dalam bentuk pemaparan naratif, representatif tabular, termasuk dalam format matriks, grafis dan sebagainya.

3. Penarikan Kesimpulan

Penyimpulan dilakukan pada tahap akhir dari penelitian yang juga sebagai jawaban atas rumusan masalah yang diajukan pada awal penelitian.

\section{HASIL PENELITIAN DAN PEMBAHASAN}

\section{Hasil Observasi}

a. Observasi Awal

Observasi dilaksanakan pada hari Rabu, tanggal 17 Januari 2013 di kelas XI IPS 2 pada jam pertama sampai dengan jam kedua. Dari observasi yang dilakukan dengan menggunakan pedoman observasi yang akan dipakai dalam penelitian diperoleh data sebagai berikut: 


\begin{tabular}{|l|l|c|}
\hline No. & \multicolumn{1}{|c|}{ Indikator } & Skor \\
\hline 1 & Tekun menghadapi tugas & $65.89 \%$ \\
\hline 2 & Ulet menghadapi kesulitan & $69.17 \%$ \\
\hline 3 & $\begin{array}{l}\text { Memiliki minat dan } \\
\text { perhatian terhadap pelajaran }\end{array}$ & $70.42 \%$ \\
\hline 4 & $\begin{array}{l}\text { Rasa senang dan puas dalam } \\
\text { mengerjakan tugas yang } \\
\text { diberikan }\end{array}$ & $66.67 \%$ \\
\hline 5 & $\begin{array}{l}\text { Adanya hasrat dan keinginan } \\
\text { untuk berhasil }\end{array}$ & $71.18 \%$ \\
\hline 6 & $\begin{array}{l}\text { Adanya kegiatan yang } \\
\text { menarik dalam belajar }\end{array}$ & $64.58 \%$ \\
\hline Skor rata-rata & $68,45 \%$ \\
\hline
\end{tabular}

Sumber: Data Primer yang Diolah

Dari data di atas menunjukkan skor Motivasi Belajar Akuntansi siswa kelas XI IPS 2 SMA Negeri 1 Banguntapan diukur dari 6 indikator yang telah ditentukan yaitu indikator tekun menghadapi tugas sebesar $65,89 \%$, indikator ulet menghadapi kesulitan sebesar $69,17 \%$, indikator memiliki minat terhadap pelajaran sebesar $70,42 \%$, indikator rasa senang dan puas dalam mengerjakan tugas sebesar $66,67 \%$, indikator adanya hasrat dan keinginan untuk berhasil sebesar $71,18 \%$ dan indikator adanya kegiatan yang menarik dalam belajar sebesar 64,58\%. Sehingga diperoleh skor Motivasi Belajar Akuntansi sebesar 68,45\%. Hal ini bermakna bahwa Motivasi Belajar Akuntansi siswa belum optimal karena belum mencapai kriteria minimum yang ditentukan yaitu 75\%. Kurangnya keterlibatan siswa dalam pembelajaran membuat siswa kurang tertarik dan bersemangat untuk mengikuti pembelajaran.

\section{b. Siklus 1}

Pembelajaran Akuntansi dengan Model Pembelajaran Kooperatif Tipe Team Accelerated Instruction (TAI) siklus 1 dilaksanakan sebanyak dua kali pertemuan. Pertemuan 1 pada tanggal 24 April 2013 pada jam pelajaran pertama sampai dengan jam kedua dan pertemuan kedua dilaksanakan pada tanggal 1 Mei 2013 dengan materi Jurnal Penutup.

\begin{tabular}{|l|l|c|c|c|}
\hline No. & Indikator & $\begin{array}{c}\text { Skor } \\
\text { Pertemuan 1 }\end{array}$ & $\begin{array}{c}\text { Skor } \\
\text { Pertemuan 2 }\end{array}$ & $\begin{array}{c}\text { Skor } \\
\text { Siklus 1 }\end{array}$ \\
\hline 1 & Tekun menghadapi tugas & $71.88 \%$ & $73.96 \%$ & $72.92 \%$ \\
\hline 2 & $\begin{array}{l}\text { Ulet menghadapi } \\
\text { kesulitan }\end{array}$ & $72.08 \%$ & $77.92 \%$ & $75.00 \%$ \\
\hline 3 & $\begin{array}{l}\text { Memiliki minat dan } \\
\text { perhatian terhadap } \\
\text { pelajaran }\end{array}$ & $77.71 \%$ & $78.96 \%$ & $78.33 \%$ \\
\hline 4 & $\begin{array}{l}\text { Rasa senang dan puas } \\
\text { dalam mengerjakan tugas } \\
\text { yang diberikan }\end{array}$ & $73.44 \%$ & $80.21 \%$ & $76.82 \%$ \\
\hline
\end{tabular}


Jurnal Pendidikan Akuntansi Indonesia, Vol. XI, No. 2, Tahun 2013

Ardy Pratama Putra W \& Isroah

$19-31$

\begin{tabular}{|l|l|c|c|c|}
\hline No. & Indikator & $\begin{array}{c}\text { Skor } \\
\text { Pertemuan 1 }\end{array}$ & $\begin{array}{c}\text { Skor } \\
\text { Pertemuan 2 }\end{array}$ & $\begin{array}{c}\text { Skor } \\
\text { Siklus 1 }\end{array}$ \\
\hline 5 & $\begin{array}{l}\text { Adanya hasrat dan } \\
\text { keinginan untuk berhasil }\end{array}$ & $63.89 \%$ & $93.06 \%$ & $78.47 \%$ \\
\hline 6 & $\begin{array}{l}\text { Adanya kegiatan yang } \\
\text { menarik dalam belajar }\end{array}$ & $84.9 \%$ & $83.33 \%$ & $84.11 \%$ \\
\hline Skor Rata-rata & $73.56 \%$ & $80.31 \%$ & $77.60 \%$ \\
\hline
\end{tabular}

Sumber: Data Primer yang Diolah

Dari data di atas diketahui bahwa total rata-rata skor pada Siklus 1 secara keseluruhan sudah mencapai kriteria yang ditentukan yaitu sebesar 77,60\%. Namun, masih terdapat indikator yang belum mencapai kriteria yang ditentukan yaitu tekun menghadapi tugas sebesar $72.92 \%$. Dari data ini, selanjutnya akan dijadikan bahan refleksi agar pada siklus 2 semua indikator Motivasi Belajar Akuntansi mencapai kriteria yang ditentukan.

c. Siklus 2

Pembelajaran Akuntansi dengan Model Pembelajaran Kooperatif Tipe Team Accelerated Instruction (TAI) siklus 2 dilaksanakan pada tanggal 8 Mei 2013 pada jam pelajaran pertama sampai jam kedua dengan melanjutkan materi pada siklus 2 yaitu jurnal pembalik. Adapun tahapan yang dilakukan sebagai berikut:

Sumber: Data Primer yang Diolah

\begin{tabular}{|l|l|c|}
\hline No. & \multicolumn{1}{|c|}{ Indikator } & Skor \\
\hline 1 & Tekun menghadapi tugas & $78.39 \%$ \\
\hline 2 & Ulet menghadapi kesulitan & $81.04 \%$ \\
\hline 3 & Memiliki minat dan perhatian terhadap pelajaran & $83.13 \%$ \\
\hline 4 & Rasa senang dan puas dalam mengerjakan tugas yang diberikan & $82.29 \%$ \\
\hline 5 & Adanya hasrat dan keinginan untuk berhasil & $81.60 \%$ \\
\hline 6 & Adanya kegiatan yang menarik dalam belajar & $88.02 \%$ \\
\hline \multicolumn{2}{|l|}{ Skor rata-rata } & $81.89 \%$ \\
\hline
\end{tabular}

Apabila dilihat dari skor pada setiap indikator Motivasi Belajar Akuntansi telah mencapai kriteria minimal yang telah ditetapkan sebelumnya yaitu sebesar $75 \%$. Kemudian apabila dilihat dari skor keseluruhan juga diperoleh skor Motivasi Belajar Akuntansi yang telah melampaui kriteria minimal dimana diperoleh skor $81.20 \%$. Pada siklus 2 ini, semua siswa sudah mencapai kriteria yang ditentukan.

\section{Hasil Angket Siklus 1 dan Siklus 2}

Angket Motivasi Belajar Akuntansi juga didistribusikan saat pembelajaran pada setiap siklusnya. Angket ini disebarkan pada akhir pembelajaran baik pada siklus 1 maupun pada siklus 2 dimana butir pernyataan pada angket tersebut sama. Dari angket yang telah didistribusikan pada siklus 1 dan 2 dapat ditampilkan data sebagai berikut: 
Jurnal Pendidikan Akuntansi Indonesia, Vol. XI, No. 2, Tahun 2013

Ardy Pratama Putra W \& Isroah

$19-31$

\begin{tabular}{|c|l|c|c|}
\hline \multirow{2}{*}{ No. } & \multicolumn{1}{|c|}{ Indikator } & \multicolumn{2}{|c|}{ Skor } \\
\cline { 2 - 4 } & Tekun menghadapi tugas 1 & Siklus 2 \\
\hline 2 & Ulet menghadapi kesulitan & $72.92 \%$ & $78.39 \%$ \\
\hline 3 & $\begin{array}{l}\text { Memiliki minat terhadap } \\
\text { pelajaran }\end{array}$ & $78.33 \%$ & $81.04 \%$ \\
\hline 4 & $\begin{array}{l}\text { Senang mencari dan } \\
\text { memecahkan masalah }\end{array}$ & $76.82 \%$ & $82.29 \%$ \\
\hline 5 & $\begin{array}{l}\text { Adanya hasrat dan keinginan } \\
\text { untuk berhasil }\end{array}$ & $78.47 \%$ & $81.60 \%$ \\
\hline 6 & $\begin{array}{l}\text { Adanya kegiatan yang } \\
\text { menarik dalam belajar }\end{array}$ & $84.11 \%$ & $88.02 \%$ \\
\hline \multicolumn{2}{|c|}{ Skor rata-rata } & $77.60 \%$ & $81.89 \%$ \\
\hline
\end{tabular}

Berdasarkan data siklus 1 di atas menunjukkan bahwa terdapat 1 indikator yang tidak mencapai kriteria minimal yaitu indikator tekun menghadapi tugas sebesar $72,92 \%$. Sedangkan kelima indikator lainnya yaitu indikator ulet menghadapi kesulitan, indikator memiliki minat terhadap pelajaran, indikator senang mencari dan memecahkan masalah, indikator hasrat dan keinginan untuk berhasil, dan indikator adanya kegiatan yang menarik dalam belajar sudah mencapai $75 \%$, sehingga diperoleh skor pada siklus 1 sebesar 77,60\%. Pada siklus 2 mengalami perubahan dimana semua indikator sudah mencapai kriteria minimal yang ditentukan. Indikator tekun menghadapi tugas sebesar 78,39\%, indikator ulet menghadapi kesulitan sebesar $81,04 \%$, indikator Memiliki minat terhadap pelajaran sebesar $83,13 \%$, indikator Senang mencari dan memecahkan masalah sebesar $82,29 \%$, indikator adanya hasrat dan keinginan untuk berhasil sebesar $76,74 \%$, dan indikator adanya kegiatan yang menarik dalam belajar sebesar $88,02 \%$. Dari data tersebut diperoleh skor untuk siklus 2 sebesar $81,20 \%$.

\section{Pembahasan}

\section{a. Indikator tekun menghadapi tugas}

Terjadi peningkatan skor dari sebelum pembelajaran TAI ke siklus 1 sebesar 22,91\% dan peningkatan dari siklus 1 ke siklus 2 sebesar 1,57\%. Peningkatan skor Motivasi Belajar Akuntansi siswa juga ditunjukkan dari data angket dimana terjadi peningkatan sebesar $5,47 \%$ dari siklus 1 ke siklus 2. Dalam pembelajaran kooperatif TAI, kelas menjadi lebih terkoordinasi bagi siswa untuk mau mengerjakan soal yang diberikan guru secara tuntas dan tepat waktu. Pembelajaran ini dapat menambah kemampuan berpikir siswa dari berbagai sumber baik dari buku maupun dari teman-teman dalam kelompoknya sehingga siswa tidak hanya bergantung pada guru.

\section{b. Indikator ulet menghadapi kesulitan}

Sebelum pembelajaran TAI diketahui skor indikator sebesar 61,46\% kemudian terjadi peningkatan pada siklus 1 sebesar 7,03\% dan meningkat lagi pada siklus 2 sebesar $8,07 \%$. Dalam data angket juga mengalami peningkatan dari siklus 1 ke siklus 2 yaitu sebesar $6,04 \%$. Peningkatan ini terjadi karena siswa sudah mulai terbiasa dan 
berani bertanya untuk menyamakan pendapat dengan guru maupun untuk mencari pemecahan masalah dengan bertanya kepada guru serta bertanya kepada siswa lain sehingga keuletan siswa meningkat. Salah satu komponen dalam pembelajaran kooperatif yaitu mampu memotivasi siswa untuk dapat menyelesaikan tugas yang diberikan.

c. Indikator Memiliki minat terhadap pelajaran

Terjadi peningkatan skor indikator dimana di sebelum pembelajaran TAI sebesar $77,60 \%$ meningkat menjadi $86,72 \%$ dan meningkat lagi pada siklus 2 menjadi 91,67\%. Peningkatan data tersebut selaras dengan data yang diperoleh dari angket. Pada angket peningkatan skor sebesar 4,8\% dari siklus 1 sebesar 78,33\% dan siklus 2 sebesar $83,13 \%$. Dengan dilakukannya penerapan pembelajaran kooperatif Tipe TAI mampu memberikan dampak positif terhadap suasana kelas. Penyampaian materi menggunakan modul pembelajaran dapat menarik perhatian siswa sehingga siswa lebih fokus untuk memperhatikan penjelasan guru dan menimbulkan komunikasi dua arah antara siswa dengan guru yang tampak pada saat penyampaian materi guru memberikan pertanyaan, hampir semua siswa menjawabnya secara bersamaan. Dengan demikian siswa menjadi lebih cepat paham mengenai materi yang disampaikan oleh guru.

d. Indikator Senang mencari dan memecahkan masalah

Terjadi peningkatan skor sebesar $16,41 \%$ dari data awal observasi ke siklus 1 dan 5,34\% dari siklus 1 ke siklus 2. Data angket menunjukan adanya peningkatan sebesar $6,01 \%$. Siswa semakin senang jika harus mengerjakan soal karena siswa yang paling cepat dan dapat menjawab dengan benar akan mendapatkan hadiah. Siswa yang tidak mendapatkan hadiah juga merasa senang dan puas karena dapat memecahkan soal yang diberikan oleh guru.

e. Indikator adanya hasrat dan keinginan untuk berhasil

Skor indikator adanya hasrat dan keinginan untuk berhasil diperoleh dari angket saja karena untuk indikator ini tidak dapat dilakukan dengan observasi. Diperoleh skor dari data angket sebesar $78,47 \%$ pada siklus 1 dan $81,60 \%$ pada siklus 2. Data angket menunjukkan adanya peningkatan sebesar 3,13\%. Peningkatan tersebut disebabkan oleh siswa semakin tertarik untuk memenangkan kelompok terbaik, sehingga siswa semakin besar keinginannya untuk berhasil menjadi kelompok terbaik. Selain berusaha untuk menjadi kelompok terbaik, siswa juga berkeinginan untuk dapat memecahkan setiap soal dalam amplop berhadiah.

f. Indikator adanya kegiatan yang menarik dalam belajar

Skor indikator adanya kegiatan yang menarik dalam belajar juga tidak dapat diukur dengan observasi karena indikator ini berasal dari perasaan pada diri siswa, sehingga hanya digunakan angket untuk mendapatkan skor pada indikator ini. Diperoleh skor dari data angket sebesar $84,11 \%$ dari siklus 1 dan 88,02\% dari siklus 2. Data angket menunjukkan adanya peningkatan sebesar 3,91\%. Sebagian besar 
siswa tertarik dengan pembelajaran yang dilakukan dengan menggunakan modul pembelajaran karena siswa menjadi lebih aktif selama pembelajaran, siswa berani mengutarakan jawabannya, dan siswa merasa tertantang untuk menyelesaikan soal-soal yang diberikan.

Dari pembahasan terhadap keenam indikator Motivasi Belajar Akuntansi secara garis besar diperoleh peningkatan skor pada setiap indikatornya. Sesuai dengan pendapat Slavin (2005) TAI dapat memotivasi siswa agar saling mendukung dan membantu satu sama lain dalam menguasai kemampuan (belajar) yang diajarkan oleh guru. Oleh karena itu, dengan ini telah terbukti bahwa dengan implementasi Model Pembelajaran Kooperatif Tipe Team Accelerated Instruction (TAI) dapat meningkatkan Motivasi Belajar Akuntansi siswa kelas XI IPS 2 SMA Negeri 1 Banguntapan Tahun Ajaran 2012/2013.

\section{PENUTUP}

\section{Keimpulan}

Berdasarkan hasil penelitian dan pembahasan pada bab IV dapat disimpulkan bahwa Implementasi Model Pembelajaran Kooperatif Tipe Team Accelerated Instruction (TAI) dapat meningkatkan Motivasi Belajar Akuntansi Kompetensi Dasar Memahami Penyusunan Siklus Akuntansi Perusahaan Jasa siswa kelas XI IPS 2 SMA Negeri 1 Banguntapan tahun ajaran 2012/2013 yang dibuktikan dengan adanya peningkatan persentase skor Motivasi Belajar Akuntansi yang diambil melalui observasi dengan lembar observasi diperoleh skor sebesar $63,15 \%$ sebelum implementasi Model Pembelajaran Kooperatif Tipe TAI kemudian meningkat menjadi $78,26 \%$ pada siklus 1 . Pada siklus 2 terjadi peningkatan pula yaitu sebesar $2,6 \%$ atau diperoleh skor sebesar $80,86 \%$. Selain itu berdasarkan angket yang didistribusikan kepada siswa dapat disimpulkan bahwa terjadi peningkatan skor Motivasi Belajar Akuntansi sebesar 4,29\% dimana skor pada siklus 1 sebesar 77,60\% meningkat menjadi $81,89 \%$ pada siklus 2 . Dari data observasi dan angket yang diperoleh dapat disimpulkan bahwa dengan dilakukannya implementasi Model Pembelajaran Kooperatif Tipe Team Accelerated Instruction (TAI) dapat meningkatkan Motivasi Belajar Akuntansi siswa.

\section{Saran}

a. Bagi Guru

1) Guru dapat mencoba untuk melakukan implementasi Model Pembelajaran Kooperatif Tipe Team Accelerated Instruction(TAI) kompetensi dasar yang lain yang diharapkan dapat memicu peningkatan keuletan siswa dalam menghadapi kesulitan belajar sehingga siswa merasa senang dan puas dalam mengerjakan tugas yang diberikan oleh guru serta pada akhirnya siswa memiliki keinginan yang lebih besar untuk berhasil dalam belajar.

2) Guru dapat menggunakan Model Pembelajaran Kooperatif Tipe Team Accelerated Instruction(TAI) agar tercipta kondisi belajar yang menarik dan menimbulkan interaksi diantara guru dan siswa 
maupun siswa dengan siswa lain sehingga siswa tidak terjebak dengan kegiatan-kegiatan yang monoton dan mekanis.

b. Bagi Siswa

1) Siswa perlu membiasakan diri untuk lebih banyak melakukan motivasi belajar guna memperoleh pemahaman materi yang lebih baik.

2) Siswa perlu membiasakan diri dalam hal bertanya mapun menjawab pertanyaan guru untuk membantu meyakinkan siswa terhadap apa yang dipahami sebelumnya.

c. Bagi Peneliti Selanjutnya

1) Hasil penelitian ini berdasarkan enam indikator. Oleh karena itu untuk penelitian lebih lanjut diharapkan dapat menambah indikator motivasi belajar agar diperoleh hasil yang mewakili motivasi belajar siswa.

2) Untuk penelitian yang akan datang diharapkan lebih teliti dalam observasi sehingga data yang diperoleh benar-benar mewakili kondisi siswa selama proses pembelajaran berlangsung.

\section{E. DAFTAR PUSTAKA}

Al Haryono Jusup. (2001). Dasar-Dasar Akuntansi I. Yogyakarta : STIE YKPN.

Hamzah B. Uno. (2008). Teori Motivasi dan Pengukurannya Analisis di Bidang Pendidikan. Jakarta: Bumi Aksara.

Mustaqim. (2008). Psikologi Pendidikan. Yogyakarta: Pustaka Pelajar.

Oemar Hamalik. (2008). Perencanaan Pengajaran Berdasarkan Pendekatan Sistem. Jakarta: PT Bumi Aksara.

Ratna Wilis Dahar. (2011). Teori-Teori Belajar \& Pembelajaran. Jakarta: Erlangga.

Sardiman A.M. (2011). Interaksi \& Motivasi Belajar Mengajar. Jakarta: PT Raja Grafindo Persada.

Slavin, Robert E. (2009). Cooperative Learning: Teori, Riset, dan Praktik. Penerjemah: Lita. Bandung: Nusa Media.

Sugiyono. (2009). Metode Penelitian Pendidikan. Bandung: Alfabeta.

Suharsimi Arikunto. (2010). Prosedur Penelitian Suatu Pendekatan Praktik. Jakarta: Rineka Cipta.

Wina Sanjaya. (2010). Penelitian Tindakan Kelas. Jakarta: Kencana (2011). Strategi Pembelajaran Berorientasi Standar Proses Pendidikan. Jakarta: Kencana 